\title{
A STUDY ON THE HYPOGLYCAEMIC EFFECT OF TINOSPORA CORDIFOLIA IN ALBINO RATS
}

\author{
Mary Chacko P1
}

1Professor, Department of Physiology, Government Medical College, Kottayam, Kerala, India.

\section{BACKGROUND}

\section{ABSTRACT}

Diabetes mellitus is a complex metabolic disorder, which has undergone elaborate research work and is still being studied widely the world over. Ayurvedic drugs have been widely used in its treatment from the time of Charaka and Sushruta. Tinospora cordifolia has been included among these. The present study was conducted in Streptozotocin-induced albino rats.

\section{MATERIALS AND METHODS}

A non-randomised controlled trial was used. The study was done in mature healthy rats in 6 groups with 6 in each group. Preliminary studies were done in normal rats. Fasting and random blood sugar levels in normal rats were determined. Minimum effective dose of fresh aqueous juice of Tinospora was calculated. Duration of hypoglycaemic effect was found out. Glucose tolerance test was done to compare the effectiveness of test, standard and normal. Detailed studies conducted in rats rendered mild and moderately diabetic by giving Streptozotocin.

\section{RESULTS}

Mean values of fasting and random blood sugar level in 25 normal rats was found to be 50.52 and $93.04 \mathrm{mg} / \mathrm{dL} \mathrm{respectively.}$ Minimum effective dose was found out to be $400 \mathrm{mg} / \mathrm{kg}$. Blood sugar level began to fall in first hour, maximum fall was noted in third hour and the values did not return to normal even after 6 hours. Comparative glucose tolerance test showed that there was no significant difference between the hypoglycaemic effect of test (Tinospora) and standard (Tolbutamide). There was highly significant difference between the hypoglycaemic effect of test (Tinospora) and control (Distilled water).

Studies in diabetic rats (both mild and moderate) after a single dose showed that there was no significant difference between the hypoglycaemic effect of test (Tinospora) and standard (Tolbutamide). There was highly significant difference between the hypoglycaemic effect of test (Tinospora) and control (Distilled water).

\section{CONCLUSION}

There was significant reduction in blood sugar level in normal rats following a single dose of the drug, which did not return to normal after 6 hours. In Streptozotocin-induced diabetic rats (Mild and Moderate), similar effects were seen.

\section{KEY WORDS}

Diabetes Mellitus, Hypoglycaemic Effect, Tinospora Cordifolia, Albino Rats.

HOW TO CITE THIS ARTICLE: Chacko MP. A study on the hypoglycaemic effect of Tinospora cordifolia in albino rats. J. Evolution Med. Dent. Sci. 2018;7(23):2782-2788, DOI: $10.14260 /$ jemds/2018/628

\section{BACKGROUND}

Diabetes mellitus is a complex metabolic disorder, which has undergone elaborate research work and is still being studied widely the world over. India has been reported as one among the top 3 countries with highest prevalence of diabetes being $9.1 \%$ in men and $7.6 \%$ in women.

Ayurvedic drugs have been used in the treatment of diabetes mellitus from the time of Charaka and Susruta. 1,2 However, very few could reach clinical use. ${ }^{3}$ Hence, Tinospora cordifolia 4 which has been included among the hypoglycaemic agents in Ayurvedic medicine was chosen for the present study with view of developing the drug further for therapeutic utility. Since the drug has to undergo experimental studies in animals before introduction to humans, the present study was undertaken in albino rats.

'Financial or Other Competing Interest': None.

Submission 21-08-2017, Peer Review 19-05-2018,

Acceptance 28-05-2018, Published 04-06-2018.

Corresponding Author:

Dr. Mary Chacko P,

Professor,

Department of Physiology,

Government Medical College,

Kottayam-686008, Kerala, India.

E-mail: marychacko5@gmail.com

DOI: $10.14260 /$ jemds $/ 2018 / 628$
Streptozotocin, an antibiotic extracted from Streptomyces achromogenes and commercially available today in a highly purified form, is a common agent used for inducing experimental diabetes. In most species, it is selectively cytotoxic to $\beta$ cells of pancreatic islets without affecting other cells. ${ }^{5}$

The present study has been undertaken to evaluate the effectiveness of Tinospora cordifolia as a hypoglycaemic agent in normal and Streptozotocin-induced diabetic albino rats.

\section{MATERIALS AND METHODS Study Design}

Experimental intervention study design was chosen for the present study. It was a non-randomised controlled study and drugs were allocated to the rats accordingly.

\section{Study Subjects}

The study was done in mature albino rats weighing 175 - 200 gms, collected from Government Veterinary College, Thrissur.

\section{Inclusion Criteria}

Mature adult healthy rats weighing 175 - 200 gms were included in the study. 


\section{Exclusion Criteria}

Animals which were inactive or did not take feed properly were excluded from the study.

\section{Sample Size}

Sample size for preliminary studies in normal rats was 25 . For detailed study in diabetic rats sample size was 36, 6 groups of rats with 6 rats in each group. Sample size was calculated based on a similar study done by Chakrabarthy $\mathrm{T}$ and Poddar G, in which the control group and study group had a sample size of 6 each $^{6}$ and as per OECD criteria.

\section{Study Setting}

The study was conducted in the Department of Physiology, Government Medical College, Kottayam.

\section{Methodology Proper}

\begin{tabular}{|l|l|l|}
\hline \multicolumn{2}{|c|}{ The study included 2 parts } \\
A.Preliminary studies in normal rats \\
rats Determination of normal blood \\
sugar levels (Fasting \& Random - 25 rats) \\
B. Assessment of the efficacy of the test extract \\
in normal rats : 3 tests done for this
\end{tabular}

\section{A. Preliminary Studies in Normal Rats}

I. Blood sugar pattern in the experimental animal, viz. Albino rats under normal circumstances was studied. Preliminary estimation of fasting and random blood sugar was done in normal rats to get an idea about the normal levels in albino rats. Blood sample was obtained using heparinised capillary pipettes of $0.1 \mathrm{~mL}$ capacity from the orbital veins. For estimation of fasting blood sugar level, blood samples were collected from 25 rats between 8 am and 9 am after 16 hours of fasting and for random blood sugar level between $10 \mathrm{am}$ and $1 \mathrm{pm}$ from the same rats. Deproteinised whole blood was used for the study. Blood sugar estimation was done using glucose oxidase-peroxidase (GOD-POD) method. ${ }^{7}$

\section{Assessment of the Efficacy of the Test Extract in} Normal Rats: $\mathbf{3}$ Tests were done for this

1. Determination of minimum effective hypoglycaemic dose of the test extract.

2. Duration of the hypoglycaemic response following oral administration of minimum effective dose.
3. Assessment of glucose tolerance in normal rats following administration of the drug.

Fresh mature stem of Tinospora cordifolia ${ }^{8}$ was weighed, crushed mechanically and then ground well using electric mixer and filtered to remove the residues. The juice was made up to $500 \mathrm{~mL}$ in such a way that $1 \mathrm{~mL}$ of crude juice was obtained from $20 \mathrm{gm}$ of the fresh stem. Minimum effective dose of the drug was taken as the dose, which could produce $50 \%$ reduction in fasting blood sugar level 2 or 3 hours following administration.

\section{Determination of Minimum Effective Dose ${ }^{9}$}

Rats were divided into 4 groups of 6 rats. After a period of 16 hours, fasting blood samples were collected for blood sugar estimation. Each group was given a particular dose of the test juice.

\begin{tabular}{|c|c|}
\hline Group & Dose of Crude Juice (mg/kg body weight) \\
\hline I & 100 \\
\hline II & 200 \\
\hline III & 300 \\
\hline IV & 400 \\
\hline
\end{tabular}

Hourly blood samples were taken for 6 hours after administration of the drug and again after 24 hours and the hypoglycaemic response was noted. Group IV showed the optimum reduction and so further studies were done using this dose of $400 \mathrm{mg} / \mathrm{kg}$ bodyweight.

\section{Study of the duration of Hypoglycaemic Response}

They were also noted by determining hourly blood sugar levels in the same rats for 6 hours after administration of the drug and again after 24 hours.

3. Assessment of Glucose Tolerance in normal rats following Administration of the Drug10

This was done in comparison with the standard oral antidiabetic drug, tolbutamide. Three groups of normal albino rats were chosen with 6 rats in each group. They were subjected to the following treatment at 8 am following a period of 16 hours of fasting. Before giving the drug, blood samples were collected from all the animals for blood sugar estimation.

\begin{tabular}{|c|c|c|}
\hline Group & Substance & Category \\
\hline I & $400 \mathrm{mg} / \mathrm{kg}$ of Tinospora juice $(4 \mathrm{~mL})$ & Test \\
\hline II & $\begin{array}{c}250 \mathrm{mg} / \mathrm{kg} \text { of Tolbutamide dissolved } \\
\text { in } 4 \mathrm{~mL} \text { distilled water }\end{array}$ & Standard \\
\hline III & $4 \mathrm{~mL}$ distilled water & Control \\
\hline
\end{tabular}

After 1 hour, each animal was given $3 \mathrm{gm} / \mathrm{kg}$ bodyweight of glucose dissolved in $1 \mathrm{~mL}$ of distilled water. Hourly blood samples were collected up to $6^{\text {th }}$ hour and blood sugar estimation was done in each sample.

\section{B. Detailed Studies in Diabetic Rats}

The albino rats were rendered diabetic using Streptozotocin obtained from Sigma Chemicals, USA. Streptozotocin was dissolved in $0.1 \mathrm{~mL}$ citrate buffer just before injection. The $\mathrm{pH}$ was adjusted between 4.3 and 4.5 . It was given to the rats by intraperitoneal injection. Depending on the dose of the drug 11,12 administered as shown in table, rats developed mild and moderate diabetes respectively in 24 to 48 hours. 


\begin{tabular}{|c|c|c|}
\hline Group & Dose of Streptozotocin & Category \\
\hline I & $30 \mathrm{mg} / \mathrm{kg}$ & Mild \\
\hline II & $65 \mathrm{mg} / \mathrm{kg}$ & Moderate \\
\hline
\end{tabular}

1. Group I showed a blood sugar level of $130-200 \mathrm{mg} / \mathrm{dL}$ (18 rats).

2. Group II showed a blood sugar level of $200-300 \mathrm{mg} / \mathrm{dL}$ (18 rats).

3. Hypoglycaemic response of the test juice was studied in the two groups.

\section{Mild Diabetes}

Comparative glucose tolerance test was done in the mildly diabetic rats. 18 mildly diabetic rats were subdivided into 3 groups of 6 each. After a period of fasting of 16 hours, blood samples were collected from all the rats and they were treated in the following way.

\begin{tabular}{|c|c|c|}
\hline Group & Substance & Category \\
\hline I & $400 \mathrm{mg} / \mathrm{kg}$ of Tinospora juice $(4 \mathrm{~mL})$ & Test \\
\hline II & $\begin{array}{c}250 \mathrm{mg} / \mathrm{kg} \text { of Tolbutamide dissolved in } \\
4 \mathrm{~mL} \text { distilled water }\end{array}$ & Standard \\
\hline III & $4 \mathrm{~mL}$ distilled water & Control \\
\hline
\end{tabular}

\section{Moderate Diabetes}

Comparative glucose tolerance test was done in the moderately diabetic rats. 18 moderately diabetic rats were subdivided into 3 groups of 6 each and treated in the same way as in mild diabetes for glucose tolerance studies.

Results were analysed statistically. All quantitative data were expressed as independent sample, mean and standard deviation. Two different groups were compared using unpaired ' $t$ ' test and different aspects of same group using paired ' $\mathrm{t}$ ' test. Statistical analysis was done by manual calculation. Qualitative data were expressed as proportions and Chi-square test was used.

\section{RESULTS}

All quantitative data were expressed as independent sample mean and standard deviation. Two different groups were compared using unpaired ' $\mathrm{t}$ ' test and different aspects of same group using paired ' $t$ ' test. Qualitative data were expressed as proportions and Chi-square test was used.

\section{A. Preliminary Studies in Normal Rats}

I. Determination of normal blood sugar levels: Fasting and random blood sugar levels were estimated in 25 normal healthy albino rats and the mean value was calculated.

\begin{tabular}{|c|c|c|}
\hline & $\begin{array}{c}\text { Fasting Blood Sugar } \\
\mathbf{m g} / \mathrm{dL}\end{array}$ & $\begin{array}{c}\text { Random Blood Sugar } \\
\mathrm{mg} / \mathrm{dL}\end{array}$ \\
\hline Mean value & 50.92 & 93.04 \\
\hline \multicolumn{2}{|c|}{ Table 1. Fasting and Random Blood Sugar Levels in } \\
Normal Albino Rats- Mean of 25 Samples
\end{tabular}

\section{Assessment of the Efficacy of the Test Extract in} Normal Rats-

1. Determination of Minimum Effective Hypoglycaemic Dose of the Test Extract

Four groups of normal rats were given the drug in doses of $100 \mathrm{mg}, 200 \mathrm{mg}, 300 \mathrm{mg}$ and $400 \mathrm{mg}$ per kg body weight respectively. Analysis of data regarding blood sugar level in response to different doses of the test drug in normal rats is given in Table 2 .

\begin{tabular}{|c|c|c|c|c|c|c|c|c|}
\hline \multirow{2}{*}{$\begin{array}{c}\text { Dose } \\
\text { (mg/kg } \\
\text { Body wt. }\end{array}$} & \multicolumn{8}{|c|}{ Mean Blood Sugar Level in $\mathrm{mg} / \mathrm{dL}$ at } \\
\hline & $\mathbf{0 ~ h r}$ & $1 \mathrm{hr}$ & $2 \mathrm{hrs}$ & $3 \mathrm{hrs}$ & $4 \mathrm{hrs}$ & $5 \mathrm{hrs}$ & $6 \mathrm{hrs}$ & $\begin{array}{c}24 \\
\text { hrs }\end{array}$ \\
\hline $\begin{array}{c}100 \\
\text { (Group } \\
\text { I) }\end{array}$ & 50.2 & 33.2 & 36.8 & 32.2 & 36.0 & 44.7 & 49.8 & 51.2 \\
\hline $\begin{array}{c}200 \\
\text { (Group } \\
\text { II) }\end{array}$ & 52.5 & 34.8 & 37.3 & 33.3 & 36.2 & 39.5 & 46.2 & 50.5 \\
\hline $\begin{array}{c}300 \\
\text { (Group } \\
\text { III) }\end{array}$ & 51.0 & 34.5 & 35.7 & 27.8 & 36.3 & 41.7 & 47.8 & 48.5 \\
\hline $\begin{array}{c}400 \\
\text { (Group } \\
\text { IV) }\end{array}$ & 54.0 & 34.8 & 29.3 & 26.5 & 30.2 & 33.8 & 42.2 & 48.2 \\
\hline & & & & & & & & \\
\hline
\end{tabular}

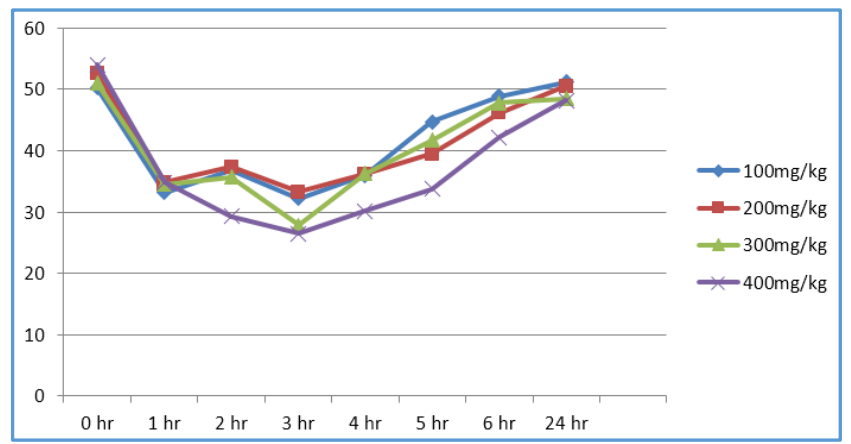

Diagram 1. Line Diagram showing Mean Blood Sugar Values in Groups of Rats given different Doses of the Drug

$\mathrm{X}$-axis- Time in hrs; $\mathrm{Y}$-axis- Dose of $\mathrm{T}$. cordifolia extract in $\mathrm{mg} / \mathrm{kg}$ body wt.

The changes in hypoglycaemic response produced by increasing doses of the drug are given in Table-3.

\begin{tabular}{|c|c|c|c|c|}
\hline $\begin{array}{c}\text { Dose (mg/kg } \\
\text { Body wt.) }\end{array}$ & \multicolumn{4}{|c|}{ Reduction in 0 - 3 Hours } \\
\hline & $\begin{array}{c}\text { \% } \\
\text { Reduction }\end{array}$ & $\begin{array}{c}\text { Mean + SD } \\
\text { (mg) }\end{array}$ & T value & P \\
\hline 100 (Group I) & 35.9 & $18.0 \pm 4.52$ & 9.78 & $<0.001$ \\
\hline 200 (Group II) & 36.6 & $19.2 \pm 3.37$ & 13.91 & $<0.001$ \\
\hline $\begin{array}{c}300 \\
\text { (Group III) }\end{array}$ & 45.5 & $23.2 \pm 3.76$ & 15.06 & $<0.001$ \\
\hline 400 (Group IV) & 50.9 & $27.5 \pm 4.23$ & 15.89 & $<0.001$ \\
\hline
\end{tabular}

Table 3. Changes in Hypoglycaemic Response produced by Increasing Doses of the Drug

\%Reduction in blood sugar level in third hour

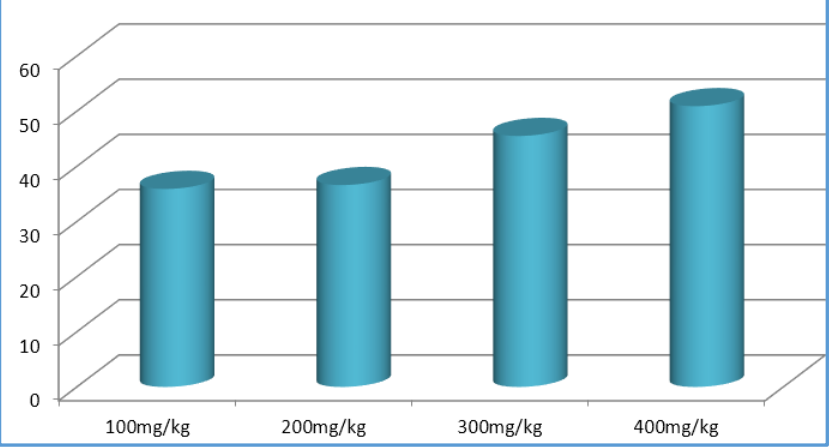

Diagram 2. Reduction in Blood Sugar Level in Third Hour in Response to Different Doses of the Drug 
$\mathrm{X}$-axis- Dose in $\mathrm{mg} / \mathrm{kg}$ body wt.; Y-axis- \% Reduction in Blood Sugar Level in Third Hour

The mean reduction in blood sugar and also the percentage reduction were seen to increase with increasing doses of the drug. Since a $50 \%$ reduction was obtained with a dose of 400 $\mathrm{mg} / \mathrm{kg}$ bodyweight, it was taken as the minimum effective dose and further studies were conducted using this dose.

\section{Duration of the Hypoglycaemic Response}

Duration of the hypoglycaemic response to the minimum effective dose of the drug, i.e. $400 \mathrm{mg} / \mathrm{kg}$ bodyweight was noted.

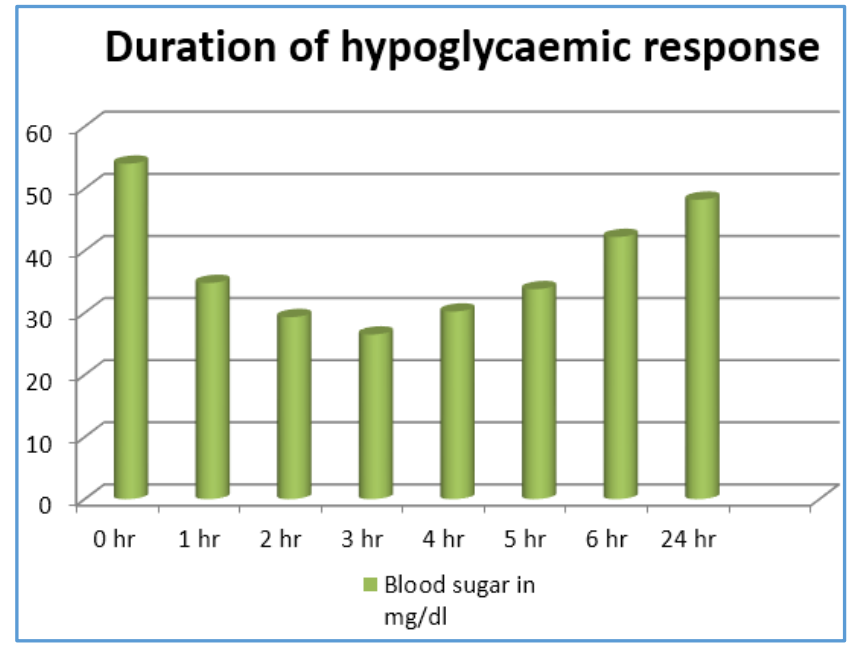

Diagram 3. Duration of Hypoglycaemic Response

$\mathrm{X}$-axis- Time in hours; Y-axis- Blood glucose in mg/dL

\section{Assessment of Glucose Tolerance in Normal Rats} following Administration of the Drug

Comparative glucose tolerance test in 3 groups of normal rats namely Group I on Tinospora juice $(400 \mathrm{mg} / \mathrm{kg})$ as Test group; Group II on Tolbutamide $(250 \mathrm{mg} / \mathrm{kg})$ as Standard; and Group III on distilled water as Control group. Mean values of the groups are plotted on the graph against time.

Blood sugar level began to fall in the first hour itself, continued to fall in the next 2 hours. The maximum reduction was observed in the third hour. Then it began to rise, but original level was not reached even by the sixth hour. A significant reduction below zero hour level was noted even at 24 hours, which leads to the conclusion that the effect of a single dose lasts for more than 24 hours.

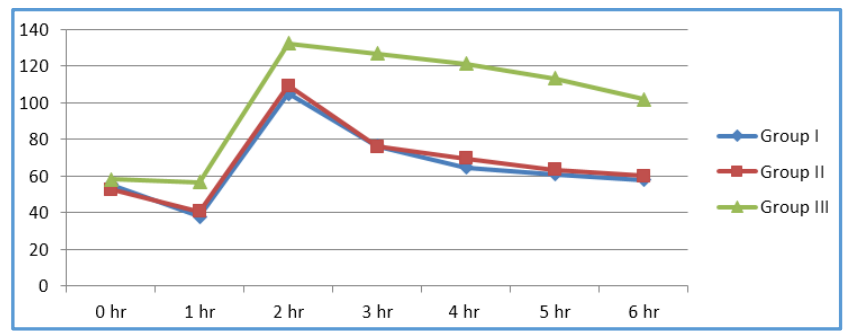

Diagram 4. Comparative Glucose Tolerance Test in Normal Rats

$\mathrm{X}$-axis- Time in hrs.; Y-axis- Blood glucose level in mg/dL.
Statistical analysis of the comparison between the hypoglycaemic response of test and control is given in Table4.

\begin{tabular}{|c|c|c|c|c|c|}
\hline $\begin{array}{c}\text { Time } \\
\text { (Hrs) }\end{array}$ & $\begin{array}{c}\text { Test (Tino } \\
\text { spora) }\end{array}$ & $\begin{array}{c}\text { Control } \\
\text { (Distilled } \\
\text { Water) }\end{array}$ & 't' value & p & $\begin{array}{c}\text { Signifi- } \\
\text { cance }\end{array}$ \\
\hline $0-1$ & $17.7 \pm 8.12$ & $1.33 \pm 1.51$ & 4.86 & $<0.005$ & $\mathrm{HS}$ \\
\hline $1-2$ & $67.2 \pm 6.70$ & $75.5 \pm 9.29$ & 1.78 & $>0.05$ & $\mathrm{NS}$ \\
\hline $2-3$ & $28.8 \pm 3.92$ & $5.7 \pm 2.94$ & 11.54 & $<0.001$ & $\mathrm{HS}$ \\
\hline $2-4$ & $40.2 \pm 4.61$ & $11.0 \pm 4.69$ & 10.93 & $<0.001$ & $\mathrm{HS}$ \\
\hline $2-5$ & $44.0 \pm 6.07$ & $19.0 \pm 6.54$ & 6.87 & $<0.001$ & $\mathrm{HS}$ \\
\hline $2-6$ & $47.0 \pm 6.54$ & $30.3 \pm 8.64$ & 3.92 & $<0.05$ & $\mathrm{~S}$ \\
\hline Table 4. Comparison between the Hypoglycaemic Response \\
of Test and Control (GTT) \\
\hline
\end{tabular}

Statistical analysis of the comparison between the hypoglycaemic response of test and standard is given in Table-5.

\begin{tabular}{|c|c|c|c|c|c|}
\hline $\begin{array}{c}\text { Time } \\
\text { (Hrs) }\end{array}$ & $\begin{array}{c}\text { Test } \\
\text { (Tinospora) }\end{array}$ & $\begin{array}{c}\text { Standard } \\
\text { (Tolbutamide) }\end{array}$ & 't' value & p & $\begin{array}{c}\text { Signifi- } \\
\text { cance }\end{array}$ \\
\hline $0-1$ & $17.7 \pm 8.12$ & $12.0 \pm 1.78$ & 1.68 & $>0.05$ & NS \\
\hline $1-2$ & $67.2 \pm 6.70$ & $68.7 \pm 6.65$ & 0.398 & $>0.05$ & NS \\
\hline $2-3$ & $28.8 \pm 3.92$ & $33.3 \pm 8.07$ & 1.23 & $>0.05$ & NS \\
\hline $2-4$ & $40.2 \pm 4.61$ & $39.2 \pm 9.68$ & 0.228 & $>0.05$ & NS \\
\hline $2-5$ & $44.0 \pm 6.07$ & $46.0 \pm 11.32$ & 0.376 & $>0.05$ & NS \\
\hline $2-6$ & $47.0 \pm 6.54$ & $49.3 \pm 10.25$ & 0.463 & $>0.05$ & NS \\
\hline \multicolumn{6}{|c|}{ Table 5. Comparison between the Hypoglycaemic } \\
Responses of Test and Standard (GTT) \\
\hline
\end{tabular}

According to this the response to glucose tolerance with the test drug is significantly greater than that of control, whereas the response in the test and standard groups were not significantly different.

\section{Detailed Studies in Diabetic Rats}

Rats rendered diabetic by intraperitoneal injection of Streptozotocin in different doses to produce mild and moderate diabetes were subjected to detailed studies. Blood sugar was noted to be in the following range:

- Mild diabetes: $130-200 \mathrm{mg} / \mathrm{dL}$.

- Moderate diabetes: $200-300 \mathrm{mg} / \mathrm{dL}$

Response to a Single Minimum Effective Dose of the Test Drug was noted in Rats with Mild and Moderate Diabetes Response to a single dose of the drug in mild diabetes is given in Table 6 and Diagram 5.

\begin{tabular}{|c|c|c|c|c|c|c|c|c|}
\hline & \multicolumn{8}{|c|}{ Blood Sugar Level in $\mathrm{mg} / \mathrm{dL}$ at } \\
\hline Time $\rightarrow$ & $0 \mathrm{hr}$ & $1 \mathrm{hr}$ & $2 \mathrm{hrs}$ & $3 \mathrm{hrs}$ & $4 \mathrm{hrs}$ & $5 \mathrm{hrs}$ & $6 \mathrm{hrs}$ & $\begin{array}{c}24 \\
\text { hrs }\end{array}$ \\
\hline $\begin{array}{l}\text { Mean } \\
\text { Values }\end{array}$ & 146.7 & 128.3 & 117.0 & 101.7 & 109.2 & 121.3 & 134.3 & 146.0 \\
\hline
\end{tabular}

On statistical analysis, it is seen that reduction in blood sugar level at third hour is highly significant compared to 0 hour ( $\mathrm{t}$ value: $24.46 ; \mathrm{p}<0.001$; highly significant). Reduction in sixth hour is also highly significant compared to basal values ( $\mathrm{t}$ value: 12.96; $\mathrm{p}<0.001$; highly significant). At 24 hours, there is no significant difference in blood sugar level from 0 hour. So the effect is seen to last for more than 6 hours. 
The hypoglycaemic response following a single dose of the drug in moderate diabetes is given in Diagram 5.

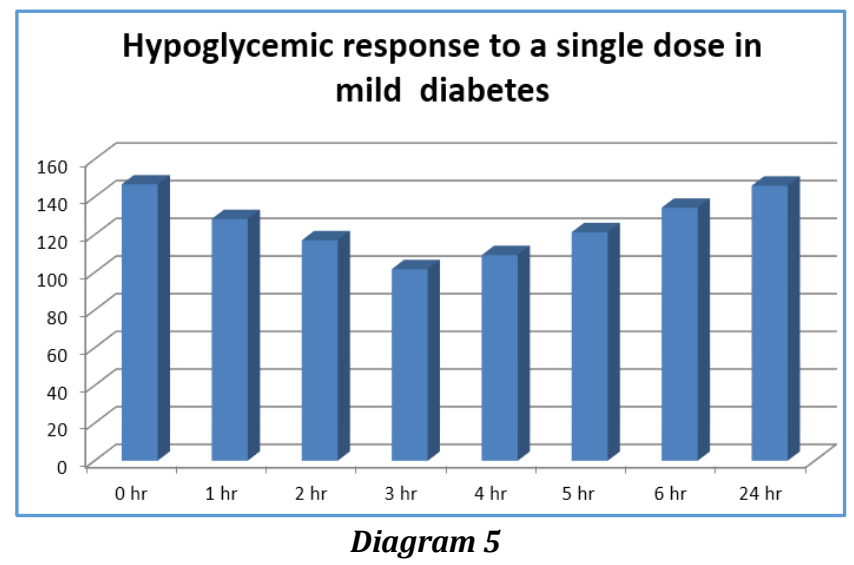

$\mathrm{X}$-axis- Time in hrs.; Y-axis- Blood glucose level in mg/dL.

Comparative glucose tolerance test in 3 groups of mildly diabetic rats namely Group I on Tinospora juice $(400 \mathrm{mg} / \mathrm{kg})$ as Test group; Group II on Tolbutamide $(250 \mathrm{mg} / \mathrm{kg})$ as Standard; and Group III on distilled water as Control group. Mean values of the groups are plotted on the graph against time. Average blood sugar values in the 3 groups is given in Diagram 6.

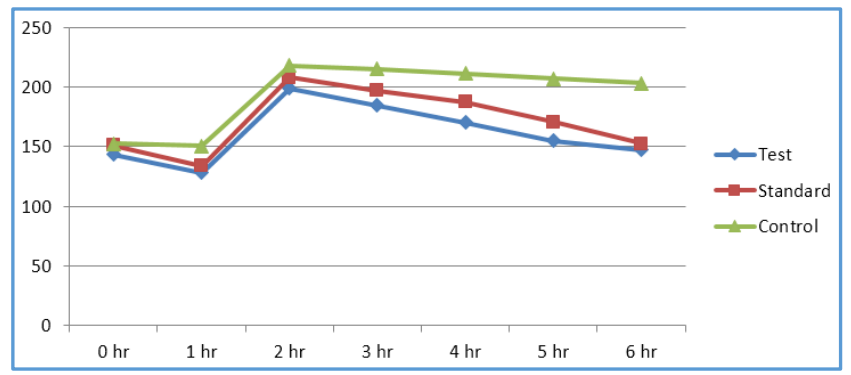

Diagram 6. Comparative Glucose Tolerance Test in Mild Diabetes

$\mathrm{X}$-axis- Time in hrs; Y-axis- Blood glucose in mg/dL.

Statistical analysis of the comparison between the hypoglycaemic response of test and control is given in Table7.

\begin{tabular}{|c|c|c|c|c|c|}
\hline $\begin{array}{c}\text { Time } \\
\text { (Hrs) }\end{array}$ & $\begin{array}{c}\text { Test } \\
\text { (Tinospora) }\end{array}$ & $\begin{array}{c}\text { Control } \\
\text { (Distilled } \\
\text { Water) }\end{array}$ & $\begin{array}{c}\text { 't' } \\
\text { value }\end{array}$ & $\mathbf{p}$ & $\begin{array}{c}\text { Signifi- } \\
\text { cance }\end{array}$ \\
\hline $0-1$ & $21.3 \pm 7.55$ & $1.7 \pm 1.51$ & 6.24 & $<0.001$ & HS \\
\hline $1-2$ & $70.7 \pm 11.08$ & $67.5 \pm 10.23$ & 0.53 & $>0.05$ & NS \\
\hline $2-3$ & $14.3 \pm 3.20$ & $3.2 \pm 2.14$ & 7.07 & $<0.001$ & HS \\
\hline $2-4$ & $28.7 \pm 3.72$ & $7.0 \pm 2.53$ & 11.79 & $<0.01$ & HS \\
\hline $2-5$ & $43.7 \pm 5.45$ & $11.0 \pm 3.16$ & 13.62 & $<0.001$ & HS \\
\hline $2-6$ & $51.3 \pm 5.45$ & $14.8 \pm 3,49$ & 11.34 & $<0.001$ & HS \\
\hline
\end{tabular}

Table 7. Comparison between the Hypoglycaemic Response of Test and Control (GTT)

Statistical analysis of the comparison between the hypoglycaemic response of test and standard is given in Table-8.

\begin{tabular}{|c|c|c|c|c|c|}
\hline $\begin{array}{c}\text { Time } \\
\text { (Hrs) }\end{array}$ & $\begin{array}{c}\text { Test } \\
\text { (Tinospora) }\end{array}$ & $\begin{array}{c}\text { Standard } \\
\text { (Tolbutamide) }\end{array}$ & $\begin{array}{c}\text { 't' } \\
\text { value }\end{array}$ & p & $\begin{array}{c}\text { Signi- } \\
\text { ficance }\end{array}$ \\
\hline $0-1$ & $21.3 \pm 7.55$ & $17.0 \pm 8.65$ & 0.918 & $>0.05$ & NS \\
\hline $1-2$ & $70.7 \pm 11.08$ & $74.0 \pm 19.59$ & 0.35 & $>0.05$ & NS \\
\hline $2-3$ & $14.3 \pm 3.20$ & $9.7 \pm 5.57$ & 1.76 & $>0.05$ & S \\
\hline $2-4$ & $28.7 \pm 3.72$ & $20.7 \pm 5.75$ & 2.86 & $<0.05$ & NS \\
\hline $2-5$ & $43.7 \pm 5.45$ & $37.3 \pm 7.34$ & 1.77 & $>0.05$ & NS \\
\hline $2-6$ & $51.3 \pm 5.45$ & $55.3 \pm 10.71$ & 0.81 & $>0.05$ & NS \\
\hline
\end{tabular}

Table 8. Comparison between the Hypoglycaemic Response of Test and Standard (GTT)

Analyses of the tables show that the difference in response of the test and control are highly significant with the test having significantly greater hypoglycaemic effect than control. The response of the test and standard are not showing significant difference.

Response to a single dose of the drug in moderate diabetes is given in Table- 9 .

\begin{tabular}{|c|c|c|c|c|c|c|c|c|}
\hline & \multicolumn{7}{|c|}{ Blood Sugar Level in mg/dL at } \\
\hline Time $\rightarrow$ & $\mathbf{0 ~ h r}$ & $\mathbf{1 ~ h r}$ & $\mathbf{2}$ hrs & $\mathbf{3} \mathbf{~ h r s}$ & $\mathbf{4} \mathbf{~ h r s}$ & $\mathbf{5}$ hrs & $\mathbf{6} \mathbf{~ h r s}$ & $\begin{array}{c}\mathbf{2 4} \\
\text { hrs }\end{array}$ \\
\hline $\begin{array}{c}\text { Mean } \\
\text { Values }\end{array}$ & 225.2 & 210.7 & 196.5 & 168.7 & 177.5 & 197.8 & 214.3 & 225.3 \\
\hline \multicolumn{6}{|c|}{ Table 9 } \\
\hline
\end{tabular}

Analysis of the data shows that there is a highly significant reduction in blood sugar in third hour compared to 0 hour ( $\mathrm{t}$ value: $12.4 ; \mathrm{p}<0.001$; highly significant). At 6 hours, the reduction is still highly significant $(\mathrm{t}$ value: 6.46 ; $\mathrm{p}<0.01$; highly significant). The values returned to 0 hour value at 24 hours.

Thus, the drug was noted to have a hypoglycaemic effect in moderate diabetes for more than 6 hours. The hypoglycaemic response following a single dose of the drug in moderate diabetes is given in Diagram-7.

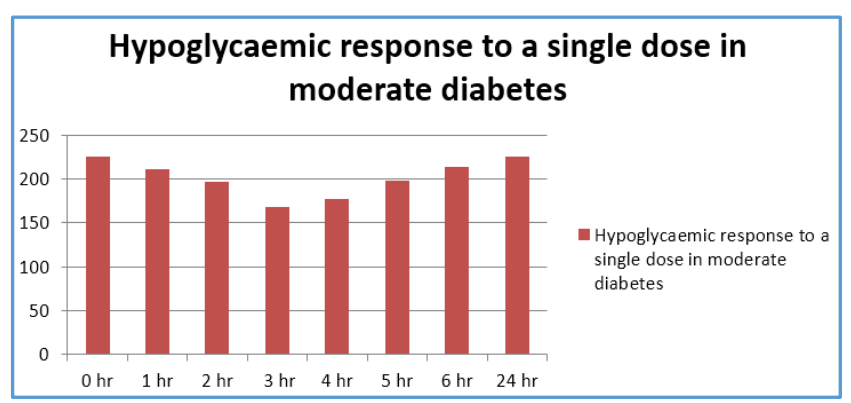

Diagram 7

$\mathrm{X}$-axis- Time in hrs; Y-axis- Blood glucose in mg/dL.

Comparative glucose tolerance test in 3 groups of moderately diabetic rats namely Group I on Tinospora juice $(400 \mathrm{mg} / \mathrm{kg})$ as Test group; Group II on Tolbutamide (250 $\mathrm{mg} / \mathrm{kg}$ ) as Standard; and Group III on distilled water as Control group. Mean values of the groups are plotted on the graph against time.

Average blood sugar values in the 3 groups is given in Diagram-8. 


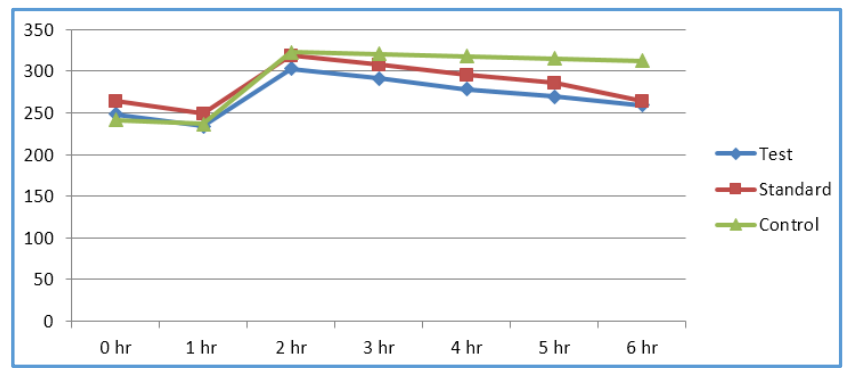

Diagram 8. Comparative Glucose Tolerance Test in Moderate Diabetes

X-axis- Time in hrs.; Y-axis- Blood glucose in mg/dL.

Statistical analysis of the comparison between the hypoglycaemic response of test and control is given in Table10.

\begin{tabular}{|c|c|c|c|c|c|}
\hline $\begin{array}{c}\text { Time } \\
\text { (Hrs) }\end{array}$ & $\begin{array}{c}\text { Test } \\
\text { (Tinospora) }\end{array}$ & $\begin{array}{c}\text { Control } \\
\text { (Distilled } \\
\text { Water) }\end{array}$ & $\begin{array}{c}\text { 't' } \\
\text { value }\end{array}$ & $\mathbf{p}$ & $\begin{array}{c}\text { Signifi- } \\
\text { cance }\end{array}$ \\
\hline $0-1$ & $14.5 \pm 5.79$ & $4.7 \pm 4.27$ & 3.33 & $<0.05$ & $\mathrm{~S}$ \\
\hline $1-2$ & $69.2 \pm 10.5$ & $86.0 \pm 22.49$ & 1.65 & $>0.05$ & $\mathrm{NS}$ \\
\hline $2-3$ & $12.5 \pm 3.08$ & $2.2 \pm 0.75$ & 2,28 & $<0.05$ & $\mathrm{~S}$ \\
\hline $2-4$ & $24.5 \pm 11.38$ & $4.7 \pm 1.03$ & 3.33 & $<0.05$ & $\mathrm{~S}$ \\
\hline $2-5$ & $33.3 \pm 13.0$ & $7.3 \pm 1.75$ & 4.85 & $<0.001$ & $\mathrm{H} \mathrm{S}$ \\
\hline $2-6$ & $43.8 \pm 10.17$ & $10.0 \pm 1.9$ & 8.00 & $<0.001$ & $\mathrm{H} \mathrm{S}$ \\
\hline \multicolumn{7}{|c|}{ Table 10. Comparison between the Hypoglycaemic } \\
Response of Test and Control (GTT) \\
\hline
\end{tabular}

\begin{tabular}{|c|c|c|c|c|c|}
\hline $\begin{array}{c}\text { Time } \\
\text { (Hrs) }\end{array}$ & $\begin{array}{c}\text { Test } \\
\text { (Tinospora) }\end{array}$ & $\begin{array}{c}\text { Standard } \\
\text { (Tolbutamide) }\end{array}$ & $\begin{array}{c}\text { 't' } \\
\text { value }\end{array}$ & p & $\begin{array}{c}\text { Signifi- } \\
\text { cance }\end{array}$ \\
\hline $0-1$ & $14.5 \pm 5.79$ & $15.3 \pm 2.07$ & 0.318 & $>0.05$ & NS \\
\hline $1-2$ & $69.2 \pm 10.5$ & $69.7 \pm 9.91$ & 0.084 & $>0.05$ & NS \\
\hline $2-3$ & $12.5 \pm 3.08$ & $11.0 \pm 4.14$ & 0.71 & $>0.05$ & NS \\
\hline $2-4$ & $24.5 \pm 11.38$ & $23.0 \pm 7.13$ & 0.27 & $>0.05$ & NS \\
\hline $2-5$ & $33.3 \pm 13.0$ & $33.0 \pm 8.16$ & 0.047 & $>0.05$ & NS \\
\hline $2-6$ & $43.8 \pm 10.17$ & $54.7 \pm 13.24$ & 1.6 & $>0.05$ & NS \\
\hline \multicolumn{6}{|c|}{ Table 11. Comparison between the Hypoglycaemic } \\
Response of Test and Standard (GTT) \\
\hline
\end{tabular}

The tables show that the test juice has a significantly greater hypoglycaemic response than the control. But the response of the test and standard are not significantly different, though the test drug produces a marginally greater response in second and sixth hours.

\section{DISCUSSION}

In the present study, the minimum effective dose of Tinospora cordifolia aqueous extract was found to be 400 $\mathrm{mg} / \mathrm{dL}$, which was found to produce reduction in blood sugar within one hour. Maximum reduction was seen in the third hour in normal rats. The hypoglycaemic effect lasted for 6 hours and levels remained below normal for over 24 hours.

Similar effects were noted in rats rendered diabetic with Streptozotocin, both mild and moderate, effects in moderate diabetes was less compared to mild.

Comparative glucose tolerance tests in normal rats, mild and moderate diabetes showed that Tinospora has hypoglycaemic effects similar to Tolbutamide

Further studies on short-term administration of the drug and toxic effects if any are worth pursuing.

\section{CONCLUSION}

The following conclusions were drawn from the study. The minimum effective dose of the drug in the study group was found to be $400 \mathrm{mg} / \mathrm{kg}$ body weight. In normal rats, this dose was seen to produce a reduction in blood sugar which started in the first hour, maximum in the third hour and there was significant reduction at 6 hours. By 24 hours, the values did not return to 0 hour value.

In mild diabetes hypoglycaemic effect started in the first hour, maximum in the third hour and there was significant reduction at 6 hours. By 24 hours, the values returned to the original levels.

In moderate diabetes, there was reduction in first hour. Magnitude of response in third hour was less than in mild diabetes. Significant reduction was maintained at 6 hours. By 24 hours, the values returned to the original levels.

Comparative glucose tolerance test in normal rats showed that there is no significant difference in the glucose tolerance pattern of tinospora and tolbutamide.

In mild and moderate diabetes, the reduction in blood sugar in rats on Tinospora closely resembled that of rats on tolbutamide.

From the present study, the definite hypoglycaemic effect of the crude aqueous extract of Tinospora cordifolia in albino rats was observed. It was also shown to have hypoglycaemic effect in mild and moderate Streptozotocin-induced diabetes.

\section{REFERENCES}

[1] Vaishnava HH. Diabetes mellitus. API Textbook of medicine. Vol. 1. $3^{\text {rd }}$ edn. Jaypee Brothers 1979: p. 42536.

[2] Mukherjee AB. The pathogenesis of diabetes mellitus. J Ind Med Assn 1978:61(1):25.

[3] Tripadi N. Dr. KM. Nadkarni's Indian materia medica. Vol. 2. 1st edn. Abe Books 1994: p. 239-44.

[4] Gupta SS. Prospects and perspectives of natural plant products in medicine. Indian Journal of Pharmacology 1994;26(1):1-12.

[5] Pitkin RM, Reynolds WA. Diabetogenic effects of Streptozotocin in Rhesus monkeys. Diabetes 1970;19(2):85-90.

[6] Chakrabarthy T, PoddarG. Herbal drugs in diabetesPart I: Hypoglycemic activity ofindigenous plants in Streptozotocin induced diabetic rats.JInst Chemists India 1984;56:42-3.

[7] Trinder P. Determination of blood glucose using an oxidase-peroxidase system with a noncarcinogenicchromogenic. Journal of Clinical Pathology1969;22(2):158-61.

[8] Dasthur JF. Tinosporacordifolia Miers. Medicinal plants of India and Pakistan. 2nd edn. JF Dasthur's Books 1988: p. 164-5.

[9] Pillai NR. Some pharmacological actions of 'Nimbidin'a bitter principle of Azadirachta Indicaa Juss (neem). Ind J Med Res 1980;72(2):121-3.

[10] Gupta SS, Verma SC, Garg VP, et al. Anti-diabetic effects of Tinospora cardifolia. I. Effect on FBS level, glucose tolerance and adrenaline induced hyperglycemia. Ind J Med Res 1967;55(7):733-45. 


\section{Jemds.com}

[11] Arison RN, Ciaccio EI, Glitzer MS, et al. Light and electron microscopy of lesions in rats rendered diabetic with streptozotocin. Diabetes 1967;16(1):516.
Original Research Article

[12] Kumari IKR, BaiLL, Cherian E. Hypoglycemic effect of Aeglemarmalos (Bael). Ind J Phy Pharmacol 1993;37(5):51. 